\title{
Interpretacija spasenja u svjetlu simbola Božanskog Srca Isusova prema Karlu Rahneru
}

\author{
Ivan Antunović*, Miroslav Čadek ${ }^{* *}$
}

\begin{abstract}
Sažetak
U članku koji slijedi želimo iznijeti nekoliko teoloških promišljanja Karla Rahnera o simbolu Presvetog Srca Isusova i njegovoj ulozi u kristološkoj interpretaciji povijesti spasenja.

Kongregacija za bogoštovlje i disciplinu sakramenata ukazuje na potrebu štovanja i širenja pobožnosti Presvetomu Srcu Isusovu. Na petak poslije druge nedjelje po Duhovima Crkva slavi svetkovinu Presvetog Srca Isusova. Osim liturgijskog slavlja, mnoštvo drugih izražaja pobožnosti imaju za predmet Kristovo Srce. Nema dvojbe da je pobožnost Spasiteljevu Srcu bio i jest jedan od najraširenijih i najomiljenijih izražaja crkvene pobožnosti.

Shvaćen u svjetlu božanskog Pisma, izraz»Srce Isusovo «označuje samo Kristovo otajstvo, cjelokupnost njegova bića, njegove osobe, razmatrane u svojoj najintimnijoj i bitnoj jezgri: Božji Sin, nestvorena mudrost, beskrajna ljubav, počelo spasenja i posvećenja za čitavo čovječanstvo. »Srce Isusovo«je Krist, utjelovljena i spasiteljska Riječ koja je, po sebi, nutarnje — s beskrajnom božansko-ljudskom ljubavlju - u Duhu pro-tegnuta prema Ocu i prema ljudima, svojoj braći i sestrama.

Ključne riječi: Božansko Srce Isusovo, simbol, kristologija u svjetlu Srca Isusova
\end{abstract}

\section{Uvod}

Prvi je dojam koji se može pokazati pri prvom susretu s djelima Karla Rahnera taj da smo pred izuzetno spekulativnom, teorijskom, apstraktnom i transcendentnom teologijom. Rahnerov teološki jezik, pun zavisnih rečenica teoloških i filozofskih kovanica, filozofskih kategorija preuzetih od suvremenih mislilaca i prilagođenih kako bi mogli izraziti sadržaj Objave, prilično je složen i težak. Una-

* Izv. Prof dr. sc. Ivan Antunović, Sveučilište u Zagrebu — Fakultet filozofije i religijskih znanosti. Adresa: Jordanovac 110, 10000 Zagreb, Hrvatska. E-pošta: iantunovic@ffdi.hr

** Mr. sc. Miroslav Čadek, Sveučilište u Zagrebu — Fakultet filozofije i religijskih znanosti. Adresa: Jordanovac 110, 10000 Zagreb, Hrvatska. E-pošta: m.cadek@ffdi.hr 
toč tomu, mnogi stručnjaci smatraju da je njegova teologija prvenstveno duboko prožeta mistikom. Upravo zbog toga Rahner smatra da se simboličku dimenziju, kao određenu metodu, treba primjenjivati i u teologiji, a osobito kada se govori o povijesti spasenja, u kojoj središnje mjesto zauzima upravo simboličnost Božanskog Srca Isusova. Utjelovljeni Sin Božji temeljna je istina naše vjere i zaglavni događaj našeg otkupljenja, čiji je sadržaj nazočan upravo u simbolu Srca Isusova. Sin Božji istovremeno je simbol apsolutne Božje ljubavi koja se utkala u svu zbilju ljudske povijesti kao i cjelokupnog čovječanstva koje traži tu Božju ljubav, koju Rahner izražava kroz simbol Srca Isusova. ${ }^{1}$

Mističnost kršćanskog života najadekvatnije je moguće izraziti kroz simbolične datosti. Poznata tvrdnja koju je Rahner izrekao na jednoj konferenciji u jesen 1966. godine upućuje na to da otajstva naše vjere spadaju u misterije koji mogu postati dio naše stvarnosti zahvaljujući našem iskustvu, koje najčešće izražavamo kroz određene simbole. Svjesni problematike izražene nazivom mistika, mogli bismo reći:

Pobožni čovjek sutrašnjice ili će biti »mistik«, tj. netko tko je nešto »iskusio«, ili će prestati biti pobožan, jer pobožnost sutrašnjice više neće počivati na uvjerenju koje je postalo iskustvom i osobnoj odluci koja je jednodušna, prirodna i javna, niti na religioznim običajima sviju; dakle dosad uobičajeni vjerski odgoj moći će ubuduće biti tek vrlo sekundarna inicijacija za institucionalni dio vjere. ${ }^{2}$

Prema tomu, kad govorimo o mističnom iskustvu to znači da trebamo imati neki odnos s Bogom iznutra, iz središta naše egzistencije. Zapravo, riječ je o spasenjskoj milosti koja nam je u svoj punini darovana u osobi Isusa Krista, koju Rahner izražava simbolom Srca Isusova.

Rahner, dakle, shvaća mistiku kao iskustvo Boga, iskustvo neiskustvenog, ali također kao životno povjerenje u Boga kao temelj vlastitog bića. Osobno iskustvo Boga Rahner poistovjećuje s iskustvom milosti, koje se sastoji u kontemplaciji različitih momenata svakidašnjeg života, uključujući one najmračnije životne trenutke. Upravo je R. Siebenrock u jednoj novijoj povijesnoj rekonstrukciji Rahnerove misli ustvrdio kako je teologija milosti počelo koje daje oblik čitavoj Rahnerovoj teologiji. ${ }^{3}$ J. B. Metz napisao je da je Rahnerova teologija »mistička biografija religioznoga iskustva, biografija egzistencije življene pred otajstvenim licem Božjim «. ${ }^{4}$ Kako bismo izrazili naša mistična iskustva vjere, Rahner smatra da su nam potrebni određeni simboli, a jedan je od najradikalnijih upravo simbol Božanskog Srca Isusova. U ovom članku na sljedećim stranicama želimo prikazati Rahnerovu interpretaciju spasenja u svjetlu simbola Srca Isusova.

1 Usp. K. Rahner, Grundkurs des Glaubens, Freiburg, 1976, str. 216 s.

2 K. Rahner, Nuovi Saggi : Vol 2: Spiritualità: Questioni fondamentali: Misteri della vita di Cristo: Sacramenti, Rim, 1968, str. 24.

3 R. Siebenrock, Gnade als Herz der Welt: Der Beitrag Karl Rahner zu einer zeitgemässen Gnadentheologie, u: M. Delgado i M. Lutz-Bachmann (prir.), Theologie aus Erfahrung der Gnade: Annäherungen an Karl Rahner, Berlin, 1994, str. 34.

4 J. B. Metz, Karl Rahner, Ein theologisches Leben: Theologie als mystische Biographie eines Christenmenschen heute, Stimmen der Zeit, 192 (1974), str. 308. 


\section{Rahnerova kristologija Logos-simbola kao kristologija Srca Isusova}

Premda za Rahnerov koncept sakrament-simbol nalazimo paralele u Pavlovom mysterionu, ipak pravi je izvor nadahnuća za njegovu ideju simbola ignacijanska duhovnost i osobto pobožnost prema Srcu Isusovu. ${ }^{5}$ On smatra da je ljudsko srce glavni simbol (Ursymbol) ili jednostavno kao simbol par excellence. ${ }^{6}$ To je sjedinjujuće središte osobe i središte njegova samo-izričaja. Ono označava izvorno jedinstvo vidljivog i nevidljivog, tijela i duha, osjećaja i misli, povijesti i transcendencije. Osim podudarnosti tih spomenutih vidika, Srce Isusovo također označava jedinstvo ljudskog i božanskog. Ono je izvanredni simbol Isusova čovještva i, stoga, privilegirani simbol utjelovljenog Logosa. Zato Rahnerovu kristologiju Logos-simbola možemo konkretno opisati kao kristologiju Srca Isusova.

Pojam Srca Isusova sintetizira razne vidove razvoja u Rahnerovoj kristologiji simbola i može poslužiti kao sažetak ovog članka. Budući da Srce Isusovo istovremeno objavljuje ljubav Boga koji spašava i odgovor otkupljenog čovjeka na tu ljubav, Rahnerova kristologija nadahnuta pobožnošću prema Presvetomu Srcu jedinstvena je te stoga u osnovi pripada modelu objave i kombinira pristupe odozgo i odozdo. Štoviše, budući da Srce Isusovo označava jedinstvo ljudskog i božanskog, bića i postojanja, identiteta i djelovanja, takva kristologija harmonizira ontološke, psihološke i soteriološke vidove Rahnerovih kristoloških spisa.

Treba naglasiti da simbolika izražena u pojmu Srca Isusova ponajprije govori o kristologiji odozgo. Srce Isusovo Rahner zamišlja kao sakramentalni znak milosrdne ljubavi Božje, koja se dariva kao milostivost i milosrđe prema slabomu čovjeku. ${ }^{7}$ Svojstveno Rahnerovoj kristologiji, Krist je predstavljen kao konačni simbol objavljene Božje spasiteljske ljubavi prema čovještvu. U njemu se Otac neopozivo objavio kao Bog ljubavi u odnosu prema čovjeku. S druge strane, s obzirom na naglasak na inkarnacijsku strukturu Božje ljubavi i sakramentalnosti Isusova čovještva, pobožnost prema Presvetomu Srcu pokazuje na kristologiju odozdo. Zato u Rahnerovim kristološkim spisima stvarnost i potpunost Isusova čovještva zauzimaju središnje mjesto. On neumorno kritizira naširoko rasprostranjeno monopolističko nerazumijevanje Kristova čovještva kao Logosove puke pojave ili običnog instrumenta po kojem se dogodilo spasenje ljudskog roda.

Nadalje, Rahnerova kristologija Srca Isusova ujedinjuje ontološke, psihološke i soteriološke vidove kristologije unutar modela objave. Pobožnost Presvetomu Srcu uključuje ontološko-esencijalnu kristologiju. U toj pobožnosti potvrđuje se strogo jedinstvo u razlikovanju božanskog i ljudskog. Srce Isusovo Rahner zamišlja kao stvarno iskazivanje božanske ljubavi u konkretnom ljudskom obličju. Dakle, u svojoj kristologiji Logos-simbola on naglašava izvorno jedinstvo Logosa i njegova čovještva, koje je stvoreno upravo jer je preuzeto: ipsa assumptione cre-

5 Usp. K. Rahner, Nuovi Saggi, str. 24.

6 Usp. J. H. P. Wong, Logos-Symbol in the Christology of Karl Rahner, Las - Rim, 1984, str. 263.

7 Usp. J. H. P. Wong, Logos-Symbol in the Christology of Karl Rahner, Las - Rim, 1984, str. 263. 
atur. ${ }^{8} \mathrm{~S}$ gledišta čovjekove uzdignute naravi, Rahner formulira teoriju »utjecaja/ djelovanja na« (aktualizacije), koja ne dopušta protuslovnost (neslaganje naravi) između Boga i čovjeka. Naprotiv, ta teorija djelovanja predstavlja obnovljeni model dvije naravi, koji djeluje u smislu dvaju načela integracije da stvore jednu cjelinu. ${ }^{9}$ Kao rezultat toga, Isusovo čovještvo u potpunosti aktualizirano od strane Logosa, postaje savršeni čovjek i, kao takav, samo-izričaj Logosa. Taj samoizričaj najbolje se vidi u simbolu Presvetog Srca.

Kao što Srce Isusovo nije izričaj bez teološkog značenja, beživotni simbol, tako ontološko jedinstvo Bog-čovjek zahtijeva punije značenje kada se ispituje njegov psihološko-egzistencijalni vid. To se temelji na Rahnerovoj pronicavosti u jedinstvo bića (postojanja) i znanja (spoznaje). Ontološko djelovanje Logosa u redu bivovanja za svoju unutrašnju posljedicu ima psihološku aktualizaciju u sferi svijesti. ${ }^{10}$ Rahner gleda Isusovu jedinstvenu svijest kao Sina i njegov sinovski odnos prema Ocu kao srž njegove osobnosti. Ako se srce promatra kao sjedište svijesti, Rahnerova kristologija svijesti bitno je kristologija Srca Isusova. ${ }^{11}$ Iz Srca Isusova kao iz Svetinje nad Svetinjama proizlaze najdublje čežnje za molitvom, klanjanje i sinovsku odanost Ocu. Zato je Srce Isusovo u samom središtu njegova samo-izričaja kao Sina. U svojem egzistencijalnom odnosu prema Ocu Isus objavljuje Trojedinog Boga kao i čovjekovo posinjenje, koje svoj izvorni model ima u Srcu Isusovu.

Ti Isusovi sinovski stavovi, ipak, nisu jednostavno bezlična svojstva njegova sinovstva; oni su »konstitutivna snaga simboličnosti koja se krije u njegovoj osobnosti ukoliko je on pravi Sin Božji i jedini spasitelj čovječanstva«. ${ }^{12}$ Dok Rahner tumači Isusovu sinovsku svijest u smislu temeljnog stanja (Grundbefindlichkeit), Isusovo razumijevanje samog sebe i sinovski odnos prema Ocu imaju autentičnu povijest razvoja, iako ontološko sinovstvo služi kao stalni temelj od početka. Nadalje, ljudska je povijest uistinu povijest božanskog Logosa ili vječnog Sina. Zato Rahner tvrdi da je Isusov život prava egzistencija Logosa u svijetu. ${ }^{13}$ Taj dinamični egzistencijalni pogled kristovskog događaja ima prednosti ispred statične formulacije Kalcedona. ${ }^{14}$ Isto tako, potvrđivanjem stvarne uključenosti Logosa

8 Usp. K. Rahner, Siehe dieses Herz. Prolegomena zu einer Theologie der Herz-Jesu-Verehrung, u: RahnerS III, str. 379-390.

9 Usp. J. H. P. Wong, nav. dj., str. 264.

10 Usp. Isto.

11 Usp. J. H. P. Wong, nav. dj., str. 264; K. Rahner, Jesus Christus, Sacramentum Mundi III, Freiburg, 1969., str. 199 i dalje, 207.

12 Usp. J. H. P. Wong, nav. dj., str. 264. O jedinstvu između biti i povijesti glede inkarnacije/utjelovljenja vidi: Isus Krist, IV, Sacramentum Mundi III, str. 208; usp. P. M. Fehlner, De Deo uno et trino ad mentem caroli Rahner, u: S. M. Lanzetta (ur.), Karl Rahner. Un'analisi critica. La figura, l'opera e la recezione teologica di Karl Rahner (1904-1984), Siena, 2009, str. 73ss.

13 Usp. J. Ferrer Arellano, El mistero de Cristo en Karl Rahner y su prospectiva escatologica, u: S. M. Lanzetta (ur.), Karl Rahner. Un'analisi critica. La figural, l'opera e la recezione teologica di Karl Rahner (1904-1984), Siena, 2009, str. 165ss.

14 K. Rahner, Trojstvo, u: Sacramentum Mundi III, str. 208. 
u događaj utjelovljenja, Rahnerova pozicija nadilazi onu sv. Tome, koji brani stvarni odnos od strane Logosa. ${ }^{15}$

Pod nazivom apsolutni Spasitelj, Rahner predstavlja kristovski događaj kao soteriološki znak. Kao odgovor na čovjekov vapaj za spasenjem, apsolutni Spasitelj daje se kao simbol Božjeg eshatološkog sebedarja, koji se potvrđuje u čovjekovoj radikalnoj otvorenosti prema ponuđenomu spasenju. To spasenje Rahner izražava simbolom Presvetog Srca Isusova te time želi naglasiti da je ponuđeno spasenje čovjeku zapravo Božja briga za njegovu vječnu sudbinu. Ali radikalno prihvaćanje spasenja od strane čovjeka postaje konačno i neopozivo jedino u trenutku smrti, gdje je Spasitelj u potpunosti i neopozivo ostvario naše otkupljenje. Prema tomu, Rahner želi naglasiti da je u otajstvu svoje muke i smrti na križu Isus istinski ostvario naše spasenje, a istodobno je na križu sebe očitovao kao »apsolutnog Spasitelja «. ${ }^{16}$ Kao što Rahnerova teološka disertacija E Latere Chri$s t i$ već naznačava, Isusovo probodeno srce izlijevajući krv i vodu tvori vrhunski simbol Božje milosrdne i sebedarivajuće ljubavi kao izvor čovjekova spasenja. ${ }^{17}$ $\mathrm{Na}$ taj način Srce Isusovo može služiti kao ujedinjujući simbol Kristove osobe i djela, bitka i egzistencije, utjelovljenja i otkupljenja.

Ipak, kao što je bilo rasprave u evaluacijama, Rahnerova kristologija simbola treba pojašnjenje u odnosu na sljedeće tri točke. Prvo, kao što Rahner primjećuje u zaključku E Latere Christi, Kristov život u cjelini nema samo značenje po njegovoj smrti na križu. Radije, pojedinačna otajstva njegova života imaju utjecaja na život kršćanina po njihovu »karakteru simbola «. ${ }^{18}$ Istina je da Srce Isusovo može služiti kao sintetizirajući simbol za sva Spasiteljeva djela ljubavi. Ali to ne znači da taj ujedinjujući simbol treba zamijeniti pojedinačna otajstva njegova života. Jer netko simbol Srca Isusova opaža jedino razmišljajući o raznim epizodama njegova života koje učinkovito otkrivaju njegove milosrdne stavove. Stoga bi se Rahnerovi kristološki spisi trebali više pozabaviti otajstvima Isusova života, kako bi dali konkretniji sadržaj simbolu Presvetog Srca Isusova. Ipak, njegovo razmišljanje o Kristovoj svijesti nude vrijedan temelj za narativnu kristologiju koja se bavi Isusovim životom.

Druga točka odnosi se na Rahnerovu kristologiju svijesti. On s pravom označuje sinovsku svijest kao egzistencijalnu srž Isusova sinovskog odnosa prema Ocu. Nažalost, njegovo nijekanje interpersonalnog Otac-Sin odnosa u imanentnom Trojstvu slabi ideju Isusova odnosa prema Ocu kao stvarnog simbola unutrašnjeg trinitarnog života. To nijekanje vodi prema Rahnerovoj poteškoći s konceptom osobe kao što se primjenjuje u kristologiji i Trojstvu. ${ }^{19}$ No uvjerenje je kod većine poznavalaca Rahnerova opusa da je ujedinjujući koncept osobe u kristologiji i

15 O usporedbi između Rahnerovog gledanja Logosove »egzistencije u svijetu « i Tominog izraza novus modus existendi in alio (STh I, q. 43, a 1 corp), u: Sacramentum Mundi III, str. 208s.

16 Usp. J. H. P. Wong, nav. dj., str. 265.

17 K. Rahner, E Latere Christi, str. 33-38. Vidi 1. poglavlje, I. dio. Ideja »sakramentalno-simbolične uzročnosti« Kristove smrti provlači se u Rahnerovim spisima.

18 Isto, str. 112-117.

19 Usp. njegov prijedlog termina Subsistenzweise (K. Rahner, Trojstvo, str. 109-115). 
u nauku o Trojstvu prijeko potreban za stvarnost objave. Kao moguće rješenje, predložena je definicija osobe kao svjesna subzistencija u odnosu, koja se može primijeniti na Krista kao božansku osobu i na božanske osobe u Presvetom Trojstvu. Tradicionalni nauk o Duhu Svetom kao vezi ljubavi između Oca i Sina potvrđuje predloženi koncept osobe i služi kao kritika Rahnerove pozicije. Međutim, kada je riječ o sličnosti u njihovu trinitarnom nauku, sv. Bonaventura u tom je pogledu izdvojio koristan korektiv za Rahnera. ${ }^{20}$ Primjenjujući taj tradicionalni nauk na Rahnerovu teoriju aktualizacije, Kristovu sinovsku svijest treba razumjeti kao aktualizaciju Srca Isusova po samosvijesti vječnog Sina u njegovu odnosu prema Ocu.

Treća točka odnosi se na Rahnerovu teoriju o transcendentalnom nadnaravnom egzistencijalu. Rahner je u pravu kad predstavlja Krista kao prototip ili paradigmu čovjeka. ${ }^{21}$ Ako ljudsko srce sa svojim bezgraničnim čežnjama upućuje na kristovski događaj, upravo je Spasiteljevo srce ono koje potpuno otkriva ljudsko srce čovjeku samomu. Čovjekova bezgranična čežnja za apsolutnim Bićem pokazuje se kao radikalni sinovski pokret prema Ocu. Rahner misli da je Isusovo iskustvo jedinstvenog sinovstva primjer i da je značajno za sve ljude. ${ }^{22}$ Dakle, kristovski događaj donosi ispunjenje uvijek danog nadnaravnog egzistencijala, prikazujući ga kao potpuno kristovski ili sinovski egzistencijal. Treba stoga priznati da Isusovo iskustvo sinovstva uzrokuje novi egzistencijal za čovjeka, koji je bogatiji od onoga koji je postojao prije Kristova dolaska. Nadalje, to iskustvo sinovstva također sadrži specifične karakteristike deklariranog kršćanina nasuprot onomu anonimnomu. Radikalna ljubav prema bližnjemu ili univerzalno bratstvo anonimnih kršćana na koje se poziva Rahner, u njegovoj »kristologiji traženja «23 nalazi svoj konačni temelj u univerzalnom Božjem očinstvu koje priznaje svaki deklarirani kršćanin. Stoga, Rahner smatra da se kršćaninova bit otkriva u participaciji u Isusovoj sinovskoj svijesti u odnosu prema Ocu s jedne strane, i s druge u bratskoj svijesti u odnosu prema ljudima. Ta sinovska i bratska svijest posebna je milost koja je dana kao baština kršćanima te se istodobno ona podrazumijeva kao određeno posjedovanje udjela u Srcu Isusovu kao sjedištu njegove samosvijesti.

\section{Kristologija predstavljena u jeziku srca}

Kako bi bila učinkovita, kristologija simbola mora biti predstavljena u jeziku simbola. Čovjekov specifičan organ za opažanje simbola nije intelekt kao takav, nego srce kao izvorno jedinstvo tijela i duha, uma, volje i čuvstava. Jezik simbola, stoga, jest jezik srca koji prenosi iskustvo. Izraz jezik simbola ili jezik srca ne tiče

20 Usp. Bonaventura, I Sent., dist. 32: »Pater et Filius diligunt se Spiritu Sancto.«

21 Usp. K. Rahner, Grundsätzliche Überlegungen zur Anthropologie und Protologie im Rahmen der Theologie, Mysterium Salutis. Grundriss heilsgeschichtlicher Dogmatik II, Einsiedeln —Zürich — Köln, 1965, str. 416.

22 Usp. J. H. P. Wong, nav. dj., str. 266.

23 K. Rahner, Isus Krist, Sacramentum Mundi III, str. 194-195. Usp. K. Rahner, Ich glaube an Jesus Christus, Sacramentum Mundi, str. 159s. 
se toliko samog jezika, nego još više ukazuje na ono što stoji iza toga i što namjerava prenijeti na ljude: primjerice osobno iskustvo. Eksperimentalno je znanje srca intuitivno i netematsko. Ono kombinira intelektualne, voljne i afektivne vidove u originalno jedinstvo. Dakle, jezik koji potječe iz osobnog iskustva, koji Rahner naziva stvarnim simbolom, utoliko ima moć izravnog djelovanja ukoliko prenosi iskustvo izravno u srce slušatelja. Zato govor koji se temelji na eksperimentalnom znanju srca može se s pravom opisati kao jezik simbola ili jezik srca.

Kristologija, koja predstavlja Krista kao simbol Božje ljubavi dane za čovjekovo spasenje, iznad svega treba se obraćati srcu. Krist treba biti predstavljen, kao što je učinjeno u Rahnerovim spisima, kao odgovor na najdublje čežnje čovjekova srca u potrazi za spasenjem. ${ }^{24}$ Ipak, kako bi se progovorilo srcu, potrebno je da ta kristologija nastane iz obilja srca (ex abundatia cordis). Čovjekovu srcu moguce je obratiti se samo pomoću srca. Dakle, prije govora srcima drugih, Bog se treba obratiti srcu pojedine osobe. Osoba mora pažljivo slušati Gospodina koji progovara učeniku »iz srca srcu« (cor ad cor loquitur). To znači da kristologija mora biti plod osobnog razmišljanja, iznad svega, osobno iskustvo Spasitelja. ${ }^{25}$ Jer komunicirajući drugima simbol-Krista, osoba neizbježno simbolizira osobno iskustvo Krista. ${ }^{26}$ To objašnjava Rahnerovo neprestano inzistiranje na tome da je stvarna početna točka kristologije osobno iskustvo kršćanina i živi kontakt s Isusom Kristom koji se događa u molitvi. ${ }^{27} \mathrm{U}$ kontekstu kršćanske tradicije, a osobito isusovačko-ignacijanske duhovnosti, zapaža Vorgrimler, mistika znači da Rahnerova teologija simbola srca nastaje iz molitve, da je molitva prati i da ona dovodi do molitve. Ta molitva bitno je povezana sa slušanjem Božje Riječi. ${ }^{28}$ Kao što je bilo rečeno tijekom ove studije, nekoliko od Rahnerovih temeljnih

24 O ideji da je Krist odgovor na čovjekovo pitanje vidi: K. Rahner, Inkarnacija/Utjelovljenje, Sacramentum Mundi III, str. 116-118. Krist kao ispunjenje čovjeka u potrazi za spasenjem, vidi: Kristologija, str. 5-9.

25 O Rahnerovoj teologiji koja se temelji na osobnom iskustvu usp. Y. M. J. Congar, A History of Theology, Garden City, 1968, str. 205. i dalje. Govoreći o teologiji kao cjelini Congar inzistira da učinkovita »nadnaravna kontemplacija « na način iskustva treba ići zajedno s racionalnom »teološkom kontemplacijom«. On također govori o »neusporedivom dobitku biti oboje, racionalan i mistik « na području teologije (str. 206). O iskustvu kao bitnom elementu u teologiji vidi: H. E. Lona - O. Wahl (prir.), Erfahrung als Weg: Beiträge zur Theologie und religiösen Praxis, Donauwörth, 1981.

26 Primjer slikara ikona pravoslavne crkve je važan. Prije rada provode se tjedni i mjeseci molitve, bdijenja i posta. Čak i prije negoli svetom izrazu dadne lik na slikarskom platnu, već je oblikovan u srcu slikara.

27 Prema interpretaciji stručnjaka i Rahnerovih suradnika poput Fichera, Metza, Vorgrimlera, Lehmanna, Neufelda i Wegera, Rahnerova teologija ima prvenstveno mističku dimenziju koja se izražava kroz simbole, a jedna od tih je i simbol Presvetog Srca Isusova. Usp. K. P. Fischer, Gott als das Geheimnis des Menschen: Karl Rahners theologie Anthropologie. Aspekte und Anfragen, u: Zeitschrift fur Katholiche Theologie, 113 (1991), 1-23. K. P. Fischer, Spiritualität und Theologie. Beobachtungen zum Weg von Karl Rahner Sj, u: M. Delgado - M. Lutz-Bachmann (ur.), Theologie aus Erfahrung der Gnade: Annäherungen an Karl Rahner, Berlin, 1994, str. 26-33; J. Splett, Mystisches chrisentuj? Karl Rahner zur Zukunft des Glaubens, u: theologiche Quartalschrift, Denken nach Karl Rahner, 174 (1994.), 258-271.

28 H. Vorgrimler, Karl Rahner: Sehnsucht nach dem geheimnisvollen Gott. Profil - Bilder - Texte, Freiburg, 1990, str. 15. 
kristoloških pronicavosti potječe iz njegova osobnog iskustva vjere. ${ }^{29}$ Stoga primjerice temeljna postavka blizina-razlika, koja se odnosi na odnos između Boga i svijeta, čovjekova uzdignuta narav, autonomija Isusove ljudske psihologije, univerzalna i stalna sakramentalnost Isusova čovještva, spasenjsko obilježje Kristove smrti i dr. definitivno potječu od Rahnerove ignacijanske duhovnosti Duhovnih vježbi i osobito njegova mističnog promatranja Kristove osobe, ponajviše kroz isusovačku duhovnost i duhovne vježbe svetog Ignacija.

Vrijeme je da se prisjetimo važnih pretpostavki u pogledu Rahnerove osobnosti koje su obilježile i njegovo znanstveno djelovanje. Za njega se kaže da je izvorno mistik koji traži konceptualnu jasnoću u psihološkom sustavu kako bi komunicirao svoje vjersko iskustvo u teološkim i duhovnim spisima. ${ }^{30}$ Veliki dominikanski teolog smatra da je teolog onaj koji se usuđuje ljudskim jezikom govoriti o Božjoj Riječi. Nakon što ju je slušao, posjeduje ju, ili točnije, ona njega posjeduje do te mjere da on teži misliti s njom i u njoj, tako da se sve sposobnosti razuma stavljaju u pogon unutar i u korist vjernikove mističke percepcije. ${ }^{31}$ On odbacuje svaki raskid između mistike i teologije tvrdeći: »Temeljeći se na jedinstvu vjere u kojem su transcendentnost božanske riječi i ljudski realizam usko povezani, odbijaju svako razdvajanje između mistike i teologije, kao između pozitivnog i spekulativnog. «32 Iako je okvir Rahnerova sustava obilježen njemačkom tradicijom, njegov postupak prema čovjekovomu transcendentalnomu iskustvu ima univerzalno značenje. Usprkos različitim oblicima misli, Rahnerov pristup nalazi posebno slaganje s logikom Istoka, koja je prvotno logika srca u svojem izvornom smislu. ${ }^{33}$ Usprkos apstraktnoj konceptualnosti i kompleksnosti njegova jezika, čitanje Rahnerova teološkog opusa smatra se vrijednim. To je posebno istinito u odnosu na njegovu kristologiju. Njegova kristološka zapažanja imaju svoje izvorište u njegovu osobnom iskustvu i sposoban je obratiti se srcu. U njegovim kristološkim spisima može se pronaći dragocjena fuzija (stapanje) spekulativne istančanosti i duhovne pronicavosti. Teologija i vjera u Rahnerovim kristološkim promišljanjima doista je i navlastito čimbenik duhovnog života. »Teologija se ne stvara dodajući corollariam pietatis apstraktnim tezama, odsječenim od njihove kako subjektivne tako i objektivne datosti, nego ostajanjem u dubokom jedinstvu teološkog reda. $\ll^{34} \mathrm{U}$ tom pogledu Rahner naglašava da ljudsko srce, nakon što je probuđeno beskrajnim horizontom i potaknuto nesputanom čežnjom, nalazi odmor u Srcu Isusovu, primjerice u njegovu dubokom iskustvu sinovstva i bratstva.

29 M. D. Chenu smatrao je da teološki sustavi odgovaraju određenomu izrazu duhovnosti te da je stoga uvijek potrebno održati vezu između kontemplacije i teologije. Usp. M. D. Chenu, Le Saulchoir: Una scuola di teologia, Genova, 1982, str. 32.

30 Transcendentalno iskustvo definitivno je iskustvo Deus semper major, kao što se nalazi u Duhovnim vježbama.

31 Usp. M. D. Chenu, nav. dj., str. 52.

32 Usp. Isto, str. 56.

33 Hebrejski koncept znanja ima daleko dublju konotaciju. Kineski znak za »razumjeti/shvatiti« sastavljen je od riječi za srce.

34 M. D. Chenu, nav. dj., str. 56. 
To miješanje kontemplativnog i spekulativnog ima zajednički temelj u ignacijanskoj duhovnosti, a osobito u njegovoj pobožnosti prema Presvetomu Srcu. Analogno vrhunskoj profinjenosti duše (Seelenspitze) kao izvornomu temelju volje i intelekta prije njihova razlikovanja, pobožnost prema Presvetomu Srcu za Rahnera je originalni izvor duhovnosti kao i spekulativnih spisa. ${ }^{35}$ Zanimanje za duhovnost prožima njegov dugogodišnji teološki rad.

Tijekom kršćanskih stoljeća, istaknuti teolozi bili su također veliki mistici i duhovni vođe. Mnogi od njih crpili su nadahnuće iz probodenog Spasiteljeva boka ili Srca Isusova. U 21. stoljeću, kojemu prijeti podvojenost uma i srca, racionalnog i afektivnog, spekulativnog i duhovnog, Srce Isusovo može poslužiti kao snažan simbol ujedinjenja. Žalosno je da je došlo do pada pobožnosti kao rezultat degradacije značenja srca. Obnova te pobožnosti ovisi o ispravnom razumijevanju srca u njegovu izvornom značenju i ispravnom tumačenju Srca Isusova kao simbola njegove osobe i ljubavi. Sve se to može naći u Rahnerovim spisima. Nadalje, njegova kristologija, nadahnuta pobožnošću prema Presvetomu Srcu i ovisna o dvostrukom konceptu Logos-simbol, predstavlja model kristologije koja govori jezikom srca. Pozvan od Srca Isusova govori drugima od srca k srcu. Rahnerova ideja simbola primijenjena na Srce Isusovo ključni je koncept koji uključuje njegovu čitavu osobu i ujedinjuje različite spise, primjerice duhovne, filozofske i teološke.

\section{Zaključak}

Probodeni Spasiteljev bok koji sadržava beskrajno bogatstvo mudrosti i znanja, nudi neiscrpan izvor kristološke kontemplacije i spekulacije. ${ }^{36}$ Jedinstvo između spekulativnog i kontemplativnog, spoznajnog i afektivnog, u čovjekovu odnosu prema Kristu dobro je izrazio sv. Bernard, veliki mistik otvorenog Isusova boka u sljedećoj izjavi: Christus tantum cognoscitur, quantum diligitur. ${ }^{37}$ To ima veze s iskustvenim znanjem. Snaga Rahnerova stvarnog simbola leži upravo u činjenici da označava poznatim ono što je simbolizirano na način iskustvenog znanja. U svojoj kristologiji Rahner komunicira poznavanje Krista po svojem osobnom iskustvu. U stvari, čovjekovo poznavanje Krista treba ići usporedno s iskustvom Gospodinove dobrote, a tekst koji Rahner često koristi najbolje to potkrepljuje: Gustate et videte quam bonus sit Dominus! (Ps 33,9)

35 Usp. J. H. P. Wong, nav. dj., str. 268.

36 E. Mersch opisuje Srce Isusovo kao izvor novog znanja koje dolazi od Boga: »Novo znanje pronalazi svoj put prema čovječanstvu, znanje koje čovjeku dolazi od Boga samoga i izvire iz najdubljeg središta čovječanstva, iz srca čovjeka koji je srce čitave rase - Bog daje ovo znanje koje je oblikovano u Bogo-čovjeku, ljudsko je i u isto vrijeme božansko. To je upravo ono što zovemo objava.« (op. cit., str. 395). Glede pobožnosti prema presvetomu Srcu, A. Grillmeier piše: »Od svih oblika pobožnosti prema Kristu, čašćenje Presvetoga Srca Isusova je možda najbolji vodič u otajstvo Kristova Bogo-čovještva, u svetost Njegove svijesti« (art. cit., u Teologija danas, Vol. 1, str. 195. i dalje).

37 Usp. J. H. P. Wong, nav. dj, str. 269. 
An Interpretation of Salvation in Light of the Symbol of the Divine Heart of Jesus according to Karl Rahner

Ivan Antunović*, Miroslav Čadek**

\section{Summary}

In this article we wish to present several of Karl Rahner's theological reflections on the symbol of the Divine Heart of Jesus and its role in the christological interpretation of salvation history. The Congregation for Divine Worship and the Discipline of the Sacraments points out the need to revere and spread the devotion to the Most Sacred Heart of Jesus. On the Friday following the Second Sunday after Pentecost the Church celebrates the Feast of the Most Sacred Heart of Jesus. Aside from the liturgical celebration, there are numerous other expressions of devotion to the Heart of Christ. Without a doubt, the devotion to the Saviour's Heart was and is one of the most widespread and cherished expressions of ecclesiastical devotion. When understood in light of the Divine Scripture, the phrase »Heart of Christ signifies the very mystery itself of Christ, the totality of His being, as seen at its most intimate and essential core: the Son of God, uncreated wisdom, infinite love, the principle of salvation and sanctification for all of mankind. »The Heart of Jesus « is Christ, the incarnate and salvific Word which is in itself, internally — with infinite divine-human love - extended in the Spirit to the Father and to all men, His brothers and sisters. Jesus

Key words: Divine Heart of Jesus, symbol, christology in the light of the Heart of

* Associte Professor Ivan Antunović, Ph.D., The Faculty of Philosophy and Religious Studies of The University of Zagreb. Address: Jordanovac 110, 10000 Zagreb, Croatia. E-mail: iantunovic@ffdi.hr

** Miroslav Čadek, M.Sc., The Faculty of Philosophy and Religious Studies of The University of Zagreb. Address: Jordanovac 110, 10000 Zagreb, Croatia. E-mail: m.cadek@ffdi.hr 